\title{
Effect of redox potential on chalcopyrite dissolution imposed by addition of ferrous ions
}

\author{
Ana Laura Araújo Santos ${ }^{1}$ (D) Fabiana Antonia Arena $^{2}$, Assis Vicente Benedetti ${ }^{1}$, Denise Bevilaqua ${ }^{1+}(\mathbb{D})$ \\ ${ }^{1}$ São Paulo State University (Unesp), Institute of Chemistry, Department of Biochemistry and Chemical Technology, 55 Prof. Francisco Degni \\ St, Araraquara, São Paulo 14800-060, Brazil \\ ${ }^{2}$ São Paulo State University (Unesp), Institute of Chemistry, Department of Physical Chemistry, 55 Prof. Francisco Degni St, Araraquara, São \\ Paulo 14800-060, Brazil
}

+ Corresponding author: Denise Bevilaqua, phone: +55-16-3301-9677, e-mail address: denise@iq.unesp.br

\section{ARTICLE INFO}

Article history:

Received: August 28, 2017

Accepted: November 16, 2017

Published: December 30, 2017
Keywords:

1. bioleaching

2. chalcopyrite

3. redox potential

4. ferrous ions

ABSTRACT: Copper is one of the metals with great economic interest and about $70 \%$ of it is found in nature as chalcopyrite mineral $\left(\mathrm{CuFeS}_{2}\right)$. Due to its slow dissolution kinetics, chalcopyrite dissolution is still a challenge for industries and researchers. Control of redox potential though has been said to be the key for increasing dissolution rate in chalcopyrite leaching systems. The current work investigated the effect of redox potential by ferrous ions addition on chalcopyrite (bio)leaching experiments. In abiotic systems, $90 \%$ of copper was leached into solution when redox potential was kept low (around 420 $\mathrm{mV} / \mathrm{Ag} / \mathrm{AgCl})$ whereas in bacterial systems (610 $\mathrm{mV} / \mathrm{Ag} / \mathrm{AgCl}$ ) low copper dissolution was observed.

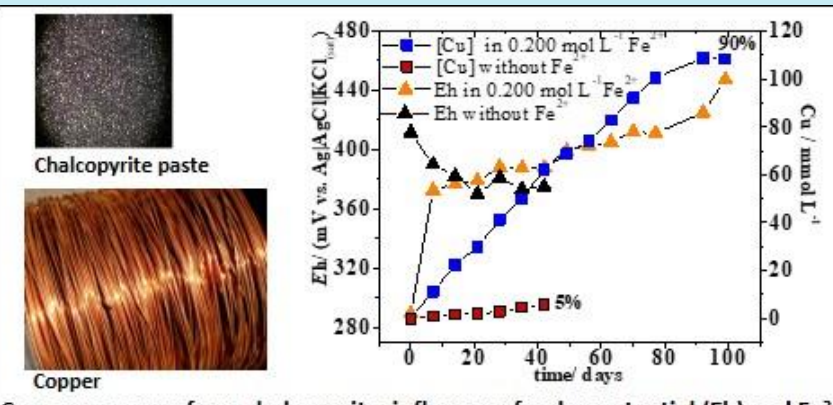

Copper recovery from chalcopyrite: influence of redox potential (Eh) and $\mathrm{Fe}^{2+}$ SEM analysis suggested presence of new phases that were confirmed by XRD to be elemental sulfur and jarosites and a significant decrease of chalcopyrite peak heights in these analyses was also observed. Jarosite was the only new phase detected in bacterial systems. Passivation of chalcopyrite surface did not occur in either conditions. The results clearly show that low redox potential along with presence of ferrous ions has positively influenced copper recovery, confirming the existence of a critical redox potential range where chalcopyrite dissolution is favored.

\section{Introduction}

Chalcopyrite is the primary copper mineral for production of copper metal. It is known to be one of the most stable copper minerals due to its structurally face-centered tetragonal lattice and for responding poorly to hydrometallurgical processes when compared to copper oxides ores ${ }^{1,2}$.

Slow dissolution rates of chalcopyrite have been attributed to a possible blockage by a superficial layer whose formation and action mechanisms on chalcopyrite are still quite contradictory in the literature. Córdoba et $\mathrm{al}^{3}{ }^{3}$ associated this layer formation with high concentration of ferric ion, consequently, high redox potential values, potentiating jarosite precipitates formation $\left(\mathrm{XFe}\left(\mathrm{SO}_{4}\right)_{2}(\mathrm{OH})_{6}\right.$ where $\mathrm{X}=\mathrm{K}^{+}, \mathrm{NH}_{4}^{+}, \mathrm{Na}^{+}$or $\mathrm{H}_{3} \mathrm{O}^{+}$) and ultimately blocking chalcopyrite surface. Studies have already discussed that the formation of a compact sulfur layer, ironbearing precipitates or jarosites has been responsible for covering chalcopyrite surface and leading to a slow and/or incomplete copper extraction ${ }^{4,5,6}$. It is noteworthy that the formation of jarosites is favored in media with high values of redox potential, such as 
bioleaching medium, in which the production of ferric ions is intense due to bacterial activity. This layer has also been described as a copper polysulfide layer, $\mathrm{CuS}_{\mathrm{n}}$ (where $\mathrm{n}>2$ ), formed during initial stages of chalcopyrite oxidation ${ }^{4}$. However, Klauber ${ }^{5}$ has claimed the characterization techniques used to identify the possible layer formed on chalcopyrite surface and stated that the only products resulting from mineral oxidation that had been demonstrated were sulfur and jarosites. The author also stated that sulfur is not able to stop chalcopyrite dissolution since this element has a relative mobility, but the formation of jarosites seems to hinder chalcopyrite dissolution.

In order to accelerate dissolution rates, jarosites precipitation must be prevented. One of the solutions discussed to overcome this issue considers the control of redox potential throughout (bio)leaching processes that could be achieved either electrochemically by applying a redox potential from an external source through a working electrode or chemically by the addition of reducing and oxidizing agents ${ }^{7}$.

The maintenance of the redox potential in a narrow range is discussed by Hiroyoshi and colleagues ${ }^{9,10}$. During the chemical leaching of chalcopyrite in ferric sulfate media, both rate and yield of copper dissolution is maximum within narrow range of redox potential around $400-450 \mathrm{mV} / \mathrm{Ag}|\mathrm{AgCl}| \mathrm{KCl}_{\text {(sat) }}$ ), whereas redox potential values above this range the blockage of mineral surface does occur mainly due to jarosite precipitation. The authors described a greater metal recovery in solutions with different ferrous, ferric and cupric ions concentrations ${ }^{9}$. The presence of certain concentrations of these ions in solution allowed the maintenance of an optimum redox potential for copper recovery due to formation of less refractory copper intermediates than chalcopyrite, such as chalcocite $\left(\mathrm{Cu}_{2} \mathrm{~S}\right)$.

The maintenance of a certain $\mathrm{Fe}^{3+} / \mathrm{Fe}^{2+}$ ratio can increase the copper extraction rate by favoring the following reactions (Equation 1 and 2) occurring in a chalcopyrite massive electrode ${ }^{10}$ :

$$
\begin{gathered}
\mathrm{CuFeS}_{2}+3 \mathrm{Cu}^{2+}+3 \mathrm{Fe}^{2+} \rightarrow 2 \mathrm{Cu}_{2} \mathrm{~S}+4 \mathrm{Fe}^{3+} \\
2 \mathrm{Cu}_{2} \mathrm{~S}+8 \mathrm{Fe}^{3+} \rightarrow 4 \mathrm{Cu}^{2+}+8 \mathrm{Fe}^{2+}+2 \mathrm{~S}^{0}
\end{gathered}
$$

Such reactions occur in a narrow potential range (400-430 mV/Ag|AgCl| $\mid \mathrm{KCl}_{\text {(sat) }}$ ) and chalcocite formation maintain chalcopyrite indirect oxidation and ferric ions concentration is insufficient for jarosite precipitation.

A bioleaching investigation including microscopy and electrochemistry showed that the presence of chalcocite significantly enhanced copper extraction and formation of jarosites seems to be insufficient for blocking the surface since these compounds are highly porous and easily lost from the surface ${ }^{11}$.

From the studies presented it is possible to note that the redox potential control apparently can improve the copper dissolution regardless of the presence or absence of precipitates.

In this context, the aim of the current work was to understand the role of redox potential in bioleaching processes by addition of different concentration of ferrous ions. It is important to emphasize that the concentrations used in this work were higher than that found in the previous literature due to our interest in study the effects of the potential in a larger range that best reflects practical conditions.

\section{Experimental Section}

\subsection{Mineral sample}

The chalcopyrite sample used in this study was obtained from La Chorrera (Cisneros, Colombia), kindly provided by Prof. Marco Antonio Marquez. The mineral was ground to $100 \%<115$ mesh $(125 \mu \mathrm{m}$ opening). The metal content was $30.86 \% \mathrm{Cu}$ and $24.4 \% \mathrm{Fe}$ by acid digestion followed by atomic absorption analysis. The X-ray diffraction (XRD) revealed the presence of chalcopyrite as only sulfide phase (Figure 1).

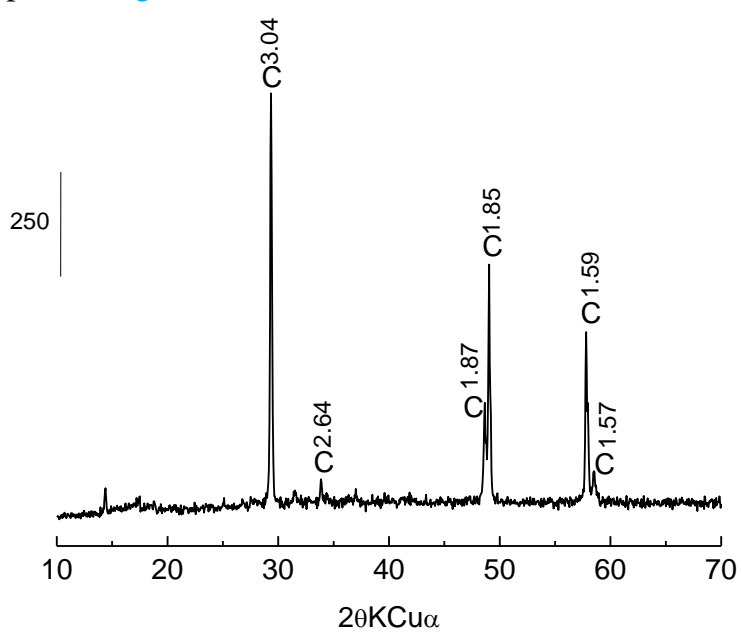

Figure 1. X-ray diffractogram of untreated chalcopyrite sample. The vertical bar shows the relative scale of counts. The d-values are given in Ångströms. 


\subsection{Bacteria and growth conditions}

Acidithiobacillus ferrooxidans, strain $\mathrm{LR}^{12}$ was used in this study. The culture was grown in mineral salts medium (MSM) which contained (per liter) $0.5 \mathrm{~g}$ $\left(\mathrm{NH}_{4}\right)_{2} \mathrm{SO}_{4}, 0.5 \mathrm{~g} \mathrm{~K}_{2} \mathrm{HPO}_{4}$, and $0.5 \mathrm{~g} \mathrm{MgSO}_{4} \cdot 7 \mathrm{H}_{2} \mathrm{O}$ at $\mathrm{pH} 1.80$ adjusted with sulfuric acid. At. ferrooxidans LR stock culture was grown using ferrous ions $(0.120$ mol L $\left.\mathrm{L}^{-1} \quad \mathrm{FeSO}_{4} \cdot 7 \mathrm{H}_{2} \mathrm{O}\right)$, as energy source, quantity enough to increase cell yields to $10^{8}$ cells $\mathrm{mL}^{-1} 13$. The mineral salts medium and the mineral sample were autoclaved at $121{ }^{\circ} \mathrm{C}$ by $20 \mathrm{~min}$ whereas ferrous sulfate was filtrated using $0.45 \mu \mathrm{m}$ membrane filter (Millipore). Aseptic techniques were used in handling, inoculation and sampling of the cultures. Cultures were incubated at $30{ }^{\circ} \mathrm{C}$ in an orbital shaker at $150 \mathrm{rpm}$. Cell counts were not determined in the experiments due to the uncertainty of distribution of attached and planktonic cells during chalcopyrite oxidation. As an approximation, the inoculation of $\mathrm{Fe}^{2+}$-grown $A t$. ferrooxidans yielded initial concentrations of the low range of $10^{8}$ cells $\mathrm{mL}^{-1}$ in chalcopyrite cultures in shake flasks.

\subsection{Acid Digestion}

The mineral sample was dried at $60{ }^{\circ} \mathrm{C}$ until constant weight. Then, $80.0 \mathrm{~mL}$ of a concentrated hydrochloric acid and nitric acid mixture (in a proportion of $3: 1$ ) was added to $2.00 \mathrm{~g}$ of the mineral sample that remained reacting for 24 hours. This mixture was heated in a hot plate and $10.0 \mathrm{~mL}$ of concentrated hydrochloric acid were added successively until substantial decrease of volume. Hydrochloric acid 50\% was added to this mixture to a final volume of $30.0 \mathrm{~mL}$ and then was filtrated using $0.45 \mu \mathrm{m}$ membrane filter (Millipore). The metalcontaining solution was analyzed by atomic absorption spectroscopy for copper and iron quantification.

\subsection{Leaching experiments}

All leaching tests were performed in an orbital shaker at $150 \mathrm{rpm}$ and $30{ }^{\circ} \mathrm{C}$ using Erlenmeyer flasks containing mineral salts medium ${ }^{13}$ at $\mathrm{pH} 1.80$ plus ferrous sulfate as energy source in different concentrations $\left(0,0.100,0.200\right.$ and $\left.0.300 \mathrm{~mol} \mathrm{~L}^{-1}\right)$ and $2.50 \%(\mathrm{w} / \mathrm{v})$ of chalcopyrite sample. Biotic conditions were performed using $5.00 \%(\mathrm{v} / \mathrm{v})$ of At. ferrooxidans
LR. The experiments were carried out in duplicate with a final volume of $150 \mathrm{~mL}$. Evaporation was compensated for adding sterile distilled water.

\subsection{Analytical procedures}

Shake flasks were periodically sampled $(3.00 \mathrm{~mL})$ in order to obtain kinetic information on metal dissolution besides $\mathrm{pH}$ and redox potential measured against $\mathrm{Ag}|\mathrm{AgCl}| \mathrm{KCl}_{\text {(sat) }}$ reference electrode. For chemical analysis, samples were centrifuged $(10,000 \mathrm{~g}$ for $15 \mathrm{~min}$ ). Aliquots of supernatants were preserved in $\mathrm{HNO}_{3} 2.0 \%$ for analysis of dissolved copper and total iron by atomic absorption spectroscopy.

Ferrous ion quantification was performed using a photocolorimetric method based on the formation of a reddish colored complex of $\mathrm{Fe}^{2+}$ with orthophenantroline. The solution was analyzed in an UV-Vis spectrophotometer at a wavelength of $510 \mathrm{~nm}^{14}$.

Finally, solid residues were characterized by XRD using the SIEMENS D5000 diffractometer equipped with a diffracted-beam monochromator and $\mathrm{CuK} \alpha$ radiation. Samples were scanned from 10 to $70^{\circ} 2 \theta$ at $0.05^{\circ} 2 \theta$ increments with $2.0 \mathrm{~s}$ counting time.

SEM-EDS analysis were carried out only in leaching final residues using a Scanning Electron Microscopy, JSM $-7500 \mathrm{~F}$, and $\mathrm{X}$ ray microanalysis, Scientific - Noran System.

\section{Results and discussion}

\subsection{Leaching experiments}

$\mathrm{pH}$, redox potential, ferrous ions and total iron concentrations were monitored throughout the experiment. The initial $\mathrm{pH}$ was set up to 1.80 , however $\mathrm{pH}$ values ranged from 1.70 to 2.50 (Figure 2). In cases of $\mathrm{pH}$ higher than 2.00 , it was necessary to adjust it to 1.80 with $\mathrm{H}_{2} \mathrm{SO}_{4}(50 \%)$ in order to avoid precipitate formation, such as jarosites, which is more auspicious in $\mathrm{pH}$ values higher than 2.00 and their formation could be unfavorable for metal recovery. In abiotic conditions, $\mathrm{pH}$ adjustments were necessary during the experiment time whereas in bacterial conditions these adjustments were required just at the beginning. Inoculated condition determined an oxidant environment that reflected in all monitored parameters. 


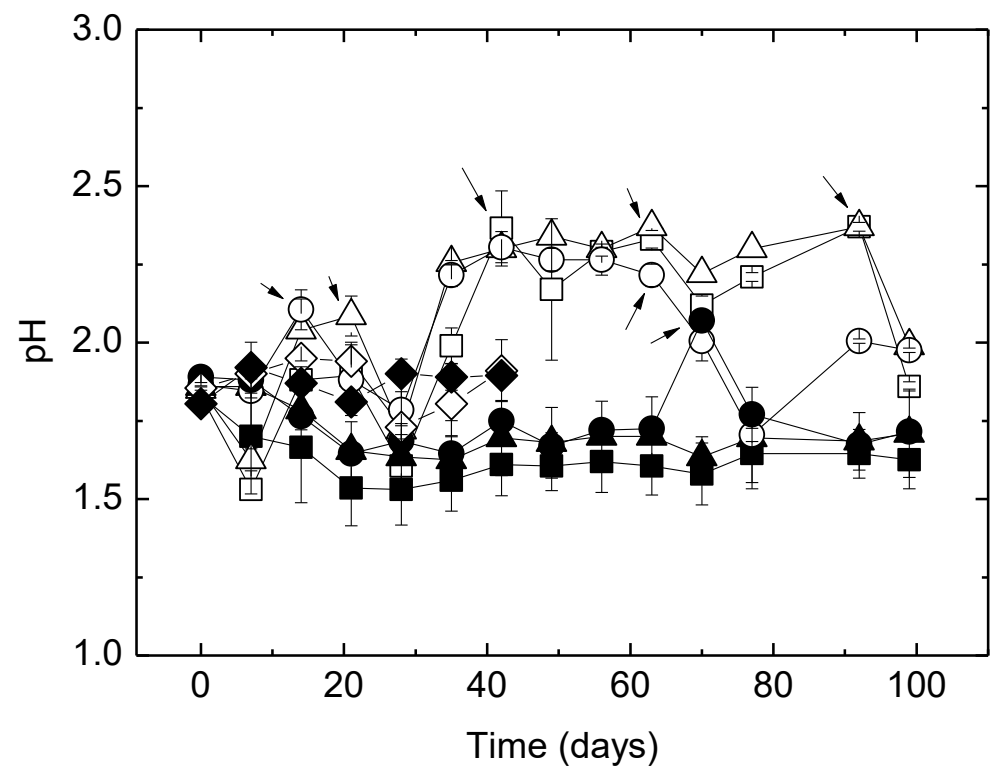

Figure 2. Changes in $\mathrm{pH}$ values on chalcopyrite leaching using different concentrations of ferrous ions in absence (open symbols) and presence (solid symbols) of bacteria. Rhombus: $0 \mathrm{~mol} \mathrm{~L}^{-1}$; square: $0.100 \mathrm{~mol} \mathrm{~L}^{-1}$; triangle: $0.200 \mathrm{~mol} \mathrm{~L}^{-1}$; and circle: $0.300 \mathrm{~mol}$ $\mathrm{L}^{-1}$ of ferrous ions. Black arrows indicate $\mathrm{pH}$ adjustment.

Figure 3 illustrates the ferrous ions consumption. In abiotic conditions ferrous ions concentration was maintained stable until the end of experiment due to the absence of an agent in solution capable of oxidizing ferrous ions in the same rate as the bacterium At. ferrooxidans. On the contrary, in inoculated conditions ferrous ions present in solution were oxidized to ferric ions within 7 days showing the bacterial capability of obtaining energy from ferrous ions and generating an extremely oxidant environment.
After 60 days a decrease in ferrous ions concentration can be clearly seen in abiotic conditions containing initial concentrations of 0.200 and 0.300 mol L ${ }^{-1}$ of $\mathrm{Fe}^{2+}$ (Figure 3). This occurrence can be explained by the ferrous ions oxidation by oxygen and/or the consumption of these ions caused by chalcopyrite reduction reaction in the presence of $\mathrm{Cu}^{2+}$ and $\mathrm{H}^{+9}$.

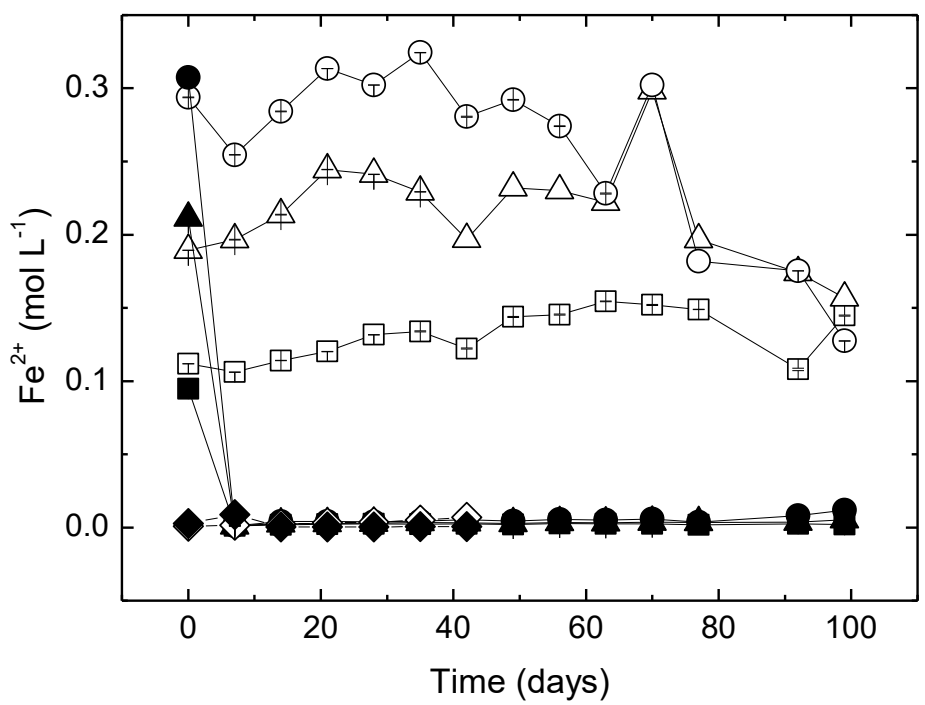

Figure 3. Changes in ferrous ions concentration on chalcopyrite leaching using different concentrations of ferrous ions in absence (open symbols) and presence (solid symbols) of bacteria. Rhombus: $0 \mathrm{~mol} \mathrm{~L}^{-1}$; square: $0.100 \mathrm{~mol} \mathrm{~L}^{-1}$; triangle: $0.200 \mathrm{~mol} \mathrm{~L}^{-1}$; and circle: $0.300 \mathrm{~mol} \mathrm{~L}^{-1}$ of ferrous ions. 
In all abiotic conditions was observed a slight increase in total soluble iron concentration $\left(\mathrm{Fe}^{2+}\right.$ and $\mathrm{Fe}^{3+}$ ) throughout the experiment, being more pronounced in the conditions containing 0.200 and $0.300 \mathrm{~mol} \mathrm{~L}^{-1}$ (data not shown) possibly due to chalcopyrite oxidation and consequent release of iron from its matrix. Under biotic conditions no significant change in total soluble iron concentration was observed in both 0.100 and $0.200 \mathrm{~mol} \mathrm{~L}^{-1} \mathrm{Fe}^{2+}$ conditions. However, total soluble iron concentration decreased during the experiment in the $0.300 \mathrm{~mol} \mathrm{~L}^{-1} \mathrm{Fe}^{2+}$ condition mainly due to bacterial activity which accelerates the conversion of ferrous into ferric ions through a proton-consuming reaction, therefore increasing $\mathrm{pH}$, favoring jarosites formation ${ }^{2,15}$.

Redox potential was also monitored throughout the experiment as presented in Figure 4. In abiotic conditions the redox potential values ranged from 300 to $470 \mathrm{mV}$ whereas in bacterial conditions the redox potential increased progressively and after 7 days of experiment it reached around $600 \mathrm{mV}$ and this value was maintained until the end.

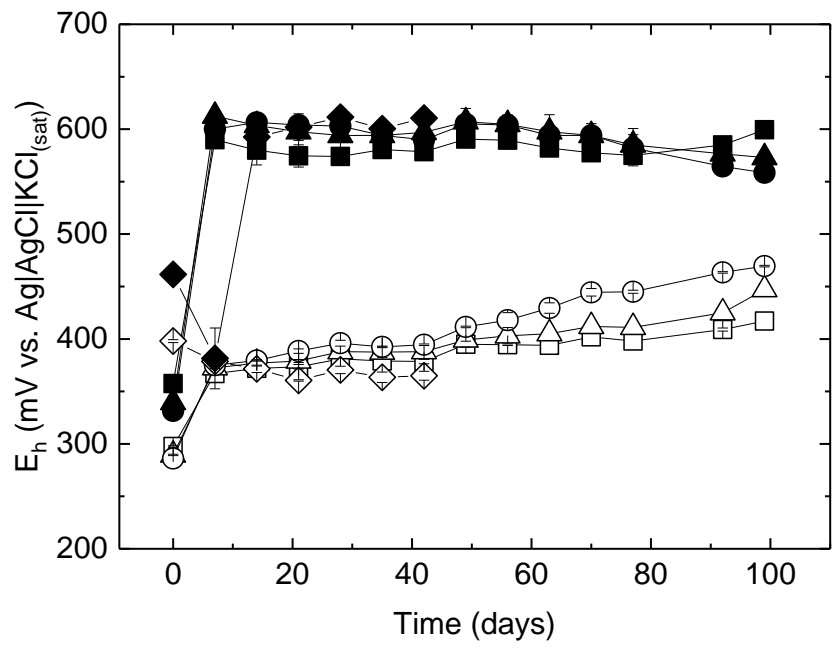

Figure 4. Redox potential measurements on chalcopyrite leaching using different concentrations of ferrous ions in absence (open symbols) and presence (solid symbols) of bacteria: rhombus- 0 mol L ${ }^{-1}$; square- $0.100 \mathrm{~mol} \mathrm{~L}^{-1}$; triangle- $0.200 \mathrm{~mol} \mathrm{~L}^{-1}$; and circle- $0.300 \mathrm{~mol} \mathrm{~L}^{-1}$ of ferrous ions.

Figure 5 shows the copper recovery in abiotic and bacterial conditions.

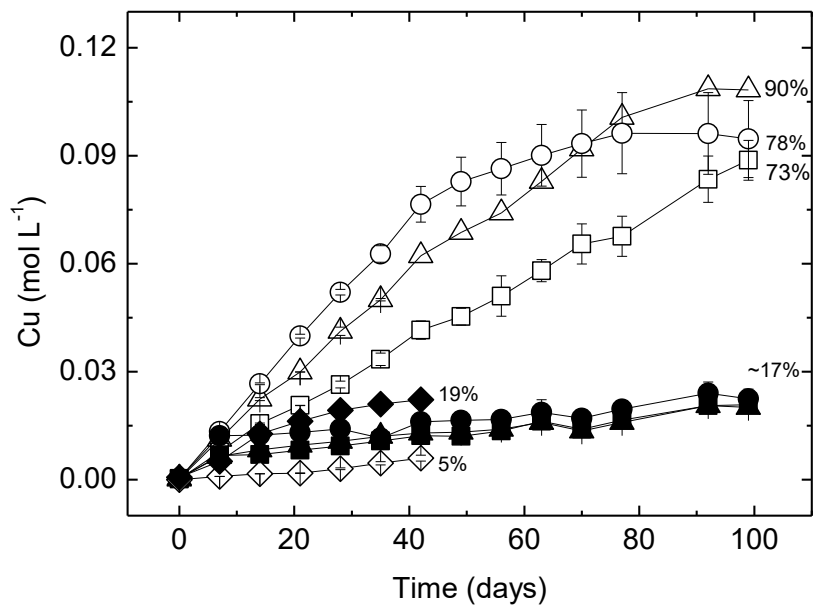

Figure 5. Time course of copper dissolution. Abiotic and bacterial conditions are represented by open and filled symbols, respectively. Rhombus: $0 \mathrm{~mol} \mathrm{~L}^{-1}$; square: $0.100 \mathrm{~mol} \mathrm{~L}^{-1}$; triangle: $0.200 \mathrm{~mol} \mathrm{~L}^{-1}$; and circle: $0.300 \mathrm{~mol} \mathrm{~L}^{-1}$ of ferrous ions. 
In this study the difference in ferrous ions concentrations in abiotic conditions was crucial to determine soluble copper concentration. The greatest copper recovery was observed in the $0.200 \mathrm{~mol} \mathrm{~L}^{-1} \mathrm{Fe}^{2+}$ condition, approximately $90 \%$ copper recovered after 100 days. For each abiotic condition tested (0, 0.100, 0.200 and $0.300 \mathrm{~mol} \mathrm{~L}^{-1}$ of ferrous ions), the final redox potential was respectively $365,410,435$ and 470 $\mathrm{mV}$, leaching about 5, 70, 90 and $80 \%$ copper, respectively. Different concentrations of ferrous ions in chalcopyrite leaching experiments resulted in different amount of copper solubilized as demonstrated previously $^{16}$ for different mineral and conditions, confirming the effect of ferrous ions concentration in chalcopyrite dissolution. The final solid residue of the $0.200 \mathrm{~mol} \mathrm{~L}^{-1} \mathrm{Fe}^{2+}$ condition was used to perform an acid digestion in order to compare with the results obtained from the liquid phase and the copper recovery obtained using this method was over $99 \%$. Both 0.100 and $0.200 \mathrm{~mol} \mathrm{~L}^{-1} \mathrm{Fe}^{2+}$ conditions presented a very similar trend regarding redox potential throughout the experiment whereas in the $0.300 \mathrm{~mol} \mathrm{~L}^{-1} \mathrm{Fe}^{2+}$ condition the redox potential starts to increase gradually after 60 days.

Copper dissolution rate decreased slightly when the redox potential reached about $420 \mathrm{mV}$ after 90 days in the $0.200 \mathrm{~mol} \mathrm{~L}^{-1} \mathrm{Fe}^{2+}$ condition and after 50 days in the $0.300 \mathrm{~mol} \mathrm{~L}^{-1} \mathrm{Fe}^{2+}$ until stops completely (Figures 4 and 5). This incident could not be seen in $0.100 \mathrm{~mol} \mathrm{~L}^{-1}$ $\mathrm{Fe}^{2+}$ because the redox potential values did not reach $420 \mathrm{mV}$ even after 100 days of experiment.

Chalcopyrite bioleaching in presence of At. ferrooxidans LR (Figure 5) resulted in a slight increase of copper dissolution rate at the beginning of experiment, followed by a decrease which was observed after 7 days and it was kept almost constant until the end of the experiment. Only $11 \%$ of copper was released into solution after 40 days in all bacterial conditions studied and even after 100 days of experiment copper recovery was not higher than $17 \%$. Despite the difference in ferrous ions concentration added to the flasks $\left(0.100,0.200\right.$ and $\left.0.300 \mathrm{~mol} \mathrm{~L}^{-1}\right)$, the final copper recovery rate obtained was almost the same value. This result was confirmed by EIS measurements for shorter immersion times in other studies $^{17,18}$, where the chalcopyrite surface seems to be partially blocked indicated by an increase of real impedance in the presence of At. ferrooxidans.

Results showed that the presence of bacteria caused a detrimental effect on copper dissolution in all concentrations studied in comparison with abiotic conditions. Low copper recovery can be associated to the high initial ferrous ions concentration readily available in solution, since bacteria prefer to oxidize soluble ferrous ions than chalcopyrite as energy source, as described by Gómez et al. ${ }^{19}$. Oxidizing chalcopyrite rather than soluble ferrous iron may favor biofilm formation that could hinder further chalcopyrite dissolution as described elsewhere ${ }^{17,18}$.

Li et $a l^{20}$ stated that the use of microbes for leaching minerals such as chalcocite, covellite and pyrite showed a beneficial effect on metal recovery; however this effect has been under discussion concerning chalcopyrite. On the other hand, some reviews have shown that there is a general acceptance that bacterial leaching of chalcopyrite does have a beneficial effect especially using high temperature and moderate thermophiles and thermophiles ${ }^{1,2}$.

Third et $a .^{21}$ carried out a series of bioleaching and chemical leaching experiments in which they concluded that the redox potential is more important for determining chalcopyrite leaching rates than bacterial activity. They also concluded that high initial ferric ions concentration and high redox potential were detrimental to chalcopyrite leaching rates whereas $\mathrm{Fe}^{2+}$-containing leaching medium raised chalcopyrite dissolution significantly.

The final residues of leaching experiments were analyzed by SEM/EDS and XRD. SEM analyses showed new crystalline phases other than chalcopyrite in solid residues. Analyses using EDS suggested them to be jarosite and elemental sulfur (Figure 6) that were confirmed by XRD analyses (Figure 7). 

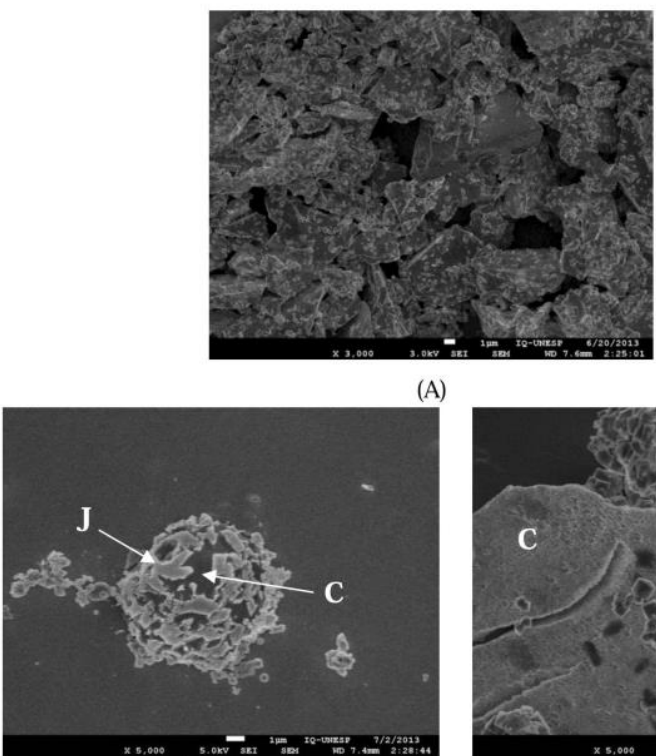

(A)

(B)

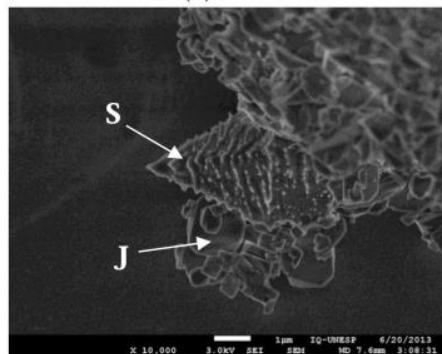

(D)

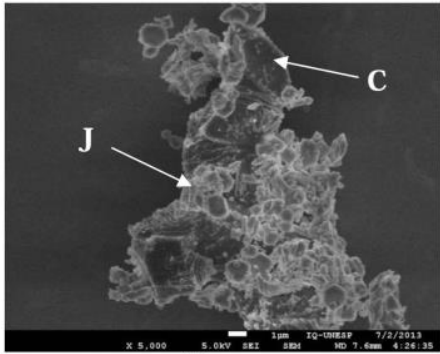

(F)

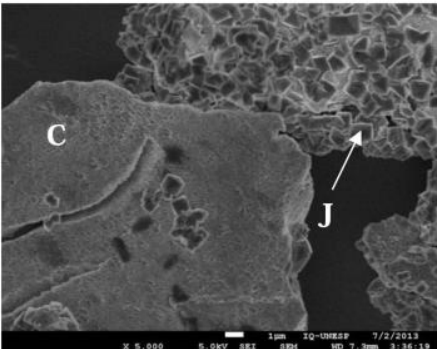

(C)

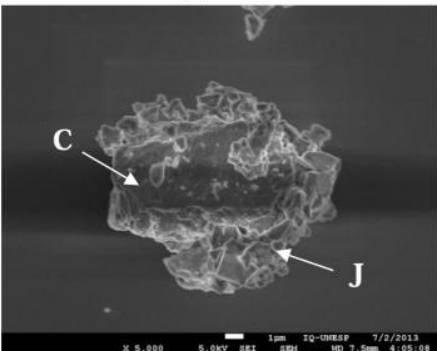

(E)

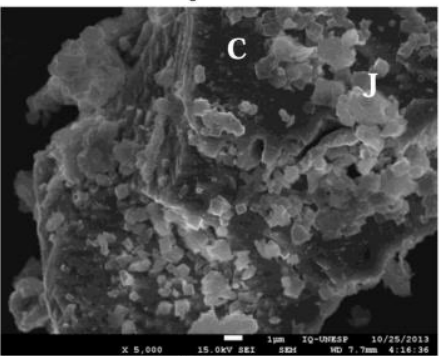

(G)

Figure 6. General outline of SEM analyses of solid residues from chalcopyrite (bio)leaching after 100 days of experiment. Untreated chalcopyrite (A); addition of $0.100 \mathrm{~mol} \mathrm{~L}^{-1} \mathrm{Fe}^{2+}$ : abiotic (B) and bacterial (C) conditions; addition of $0.200 \mathrm{~mol} \mathrm{~L}^{-1} \mathrm{Fe}^{2+}$ : abiotic (D) and bacterial (E) conditions and addition of $0.300 \mathrm{~mol} \mathrm{~L}^{-1} \mathrm{Fe}^{2+}$ : abiotic $(\mathrm{F})$ and bacterial $(\mathrm{G})$ conditions. Letter designations: $\mathrm{C}=$ chalcopyrite, $\mathrm{J}=$ jarosite and $\mathrm{S}=$ Sulfur.

Figure 7 shows X-ray patterns of an untreated chalcopyrite sample and solid residues after 100 days of leaching with addition of ferrous ions. The diffractograms showed the presence of jarosites and elemental sulfur, as cumulative phases, since sulfur formation was first observed after 14 days of experiment. It is noteworthy that the intensity of the chalcopyrite's peak has a significant decrease which confirms the percentage of recovery obtained in the leachate. In all bacterial conditions only jarosite was formed during the experiment (data not shown). In the control condition (without addition of ferrous ions) formation of a new crystalline phase was not observed. 

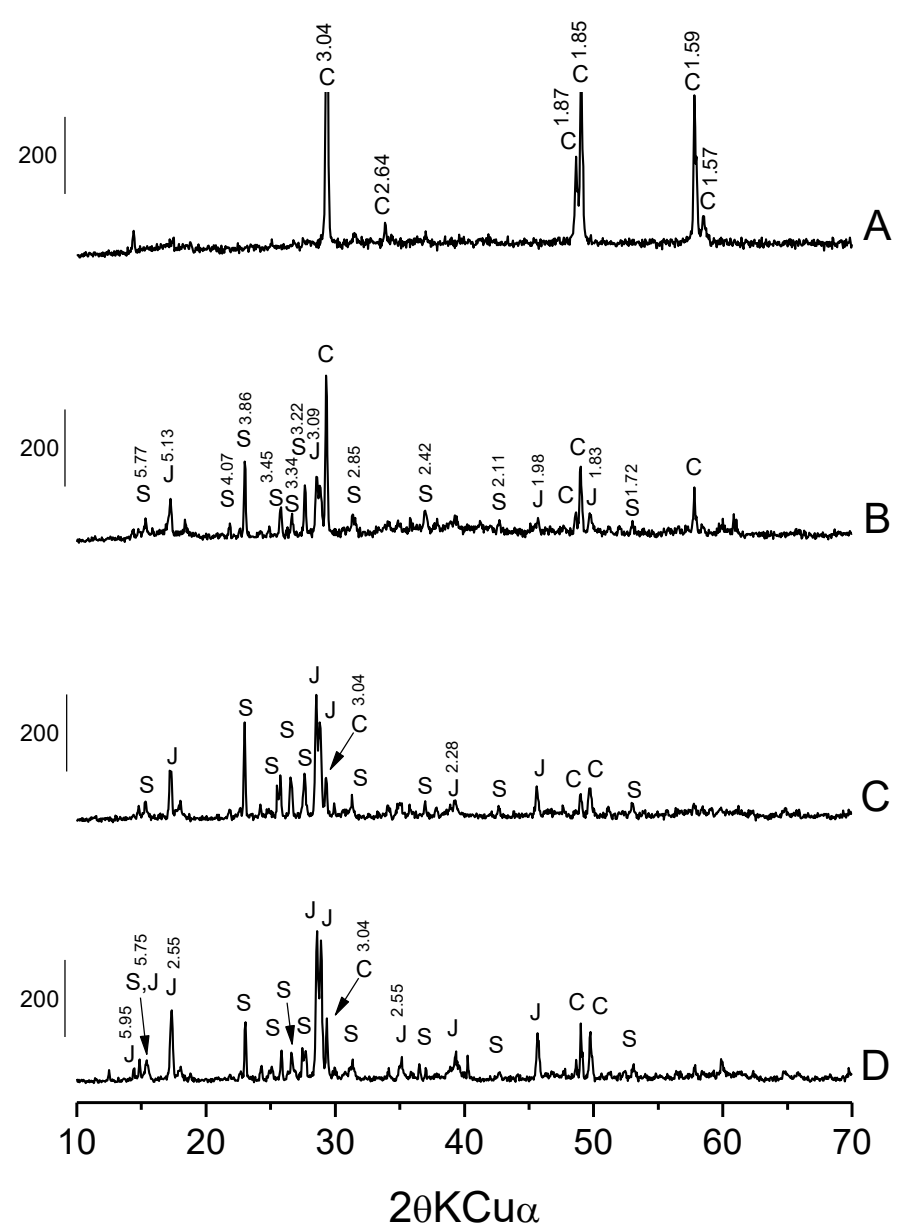

Figure 7. X-ray diffractograms of solid residues from chalcopyrite bioleaching after 100 days of experiment in abiotic conditions. A: Untreated chalcopyrite, B: addition of $0.100 \mathrm{~mol} \mathrm{~L}^{-1}, \mathrm{C}: 0.200 \mathrm{~mol} \mathrm{~L}^{-1}$ and D: $0.300 \mathrm{~mol} \mathrm{~L}^{-1}$ of ferrous ions. Letter designations: $\mathrm{C}=$ chalcopyrite, $\mathrm{J}=$ jarosite and $\mathrm{S}=$ sulfur. The vertical bar shows the relative scale of counts. The $\mathrm{d}$ values are given in Ångströms.

Previously, it has been reported that the precipitation of elemental sulfur can hinder chalcopyrite leaching as well as iron precipitates ${ }^{22,23}$. Despite the formation of elemental sulfur and its progressive accumulation, detrimental effects on chalcopyrite dissolution were not observed. On the contrary, the $0.200 \mathrm{~mol} \mathrm{~L}^{-1} \mathrm{Fe}^{2+}$ condition was able to recover over $99 \%$ of copper.

Considering the results obtained in this present work, the effect of continuous chalcopyrite dissolution can be attributed to the maintenance low redox potential as well as the presence of ferrous ions in solution. Several authors have described the positive effect of both redox potential and ferrous ions on chalcopyrite dissolution, however attributing different significance of each one ${ }^{7,9,10,21,24,25,26}$. For instance, Third et $a .^{21}$ considered the redox potential a parameter more significant to determine chalcopyrite leaching rates than bacterial cell number or their activity. The authors also stated that addition of ferrous ions to the systems increased copper dissolution rate in 2.7 fold than when the same quantity of ferric ions was added. Several other authors ${ }^{24,25,26}$ have focused only on a critical redox potential range $(400-450 \mathrm{mV})$ over which chalcopyrite (bio)leaching is hindered.

This current study showed that the control condition tested (without addition of ferrous ions and without bacteria) was the system that reached the lowest redox potential value and the lowest copper recovery. Therefore, in an optimized system, it is necessary not only low redox potential values (400-450 $\mathrm{mV}$ ) but also presence of ferrous ions to ensure higher rates of copper recovery. Recently, it was demonstrated by electrochemical impedance spectroscopy that ferrous ions activated chalcopyrite surface even in the presence of surface precipitates and the redox potential range could help the maintenance of this activation ${ }^{18}$. Thus, we propose a new approach to interpret the effect 
of ferrous ions and redox potential on chalcopyrite dissolution considering the combined effect of these parameters, since both parameters cannot be interpreted separately (Figure 8).

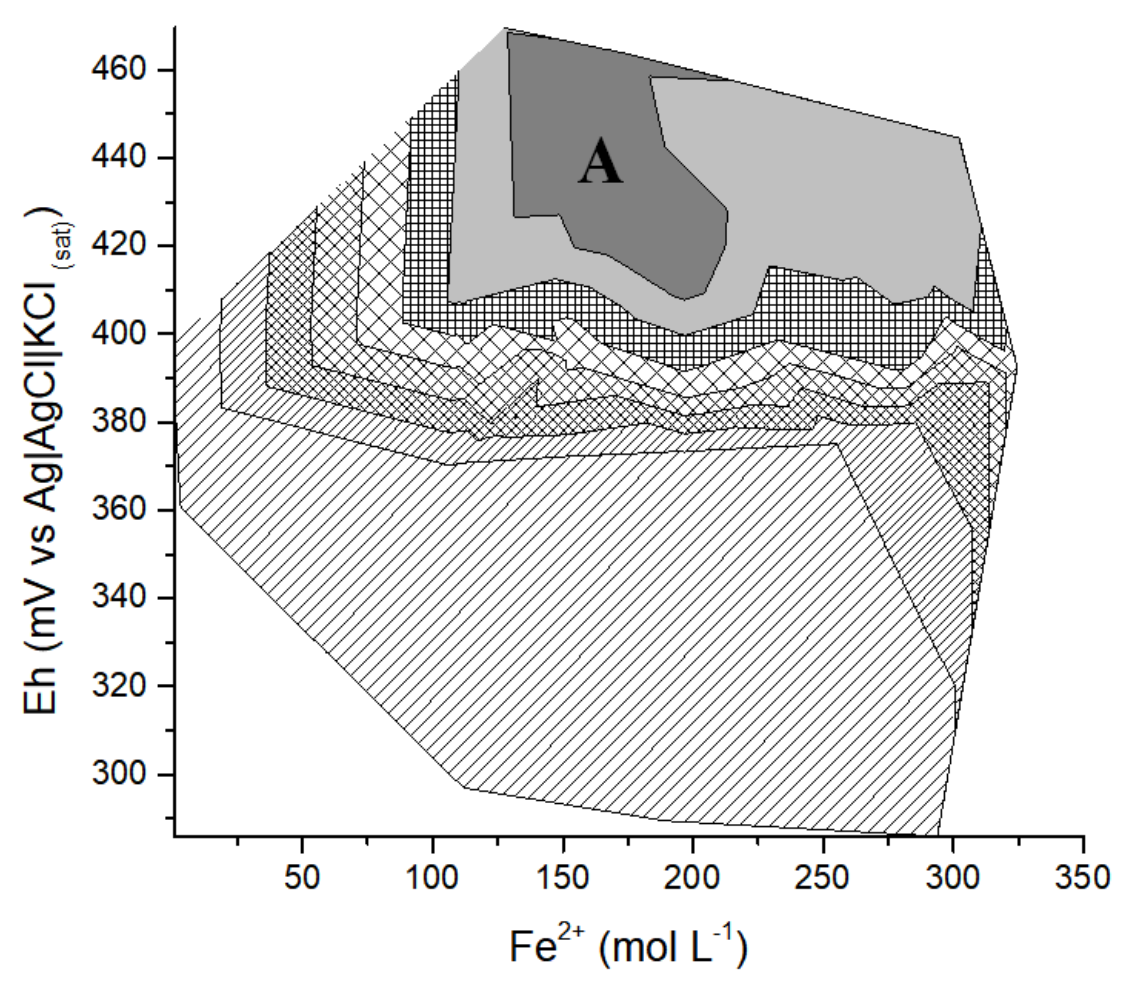

\section{$\%$ Cu recovered}

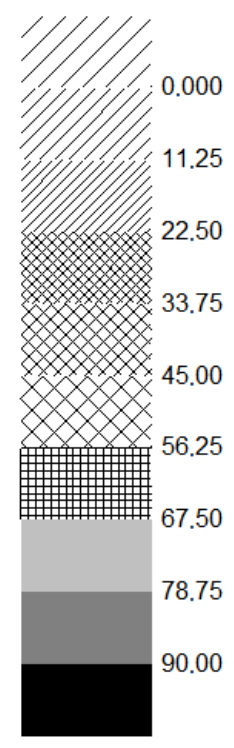

Figure 8. Combined effect of ferrous iron concentration and redox potential on chalcopyrite dissolution under abiotic condition.

Maximum copper recovery is delimited by the region defined by the dark grey color (region $\mathrm{A}$ ) where the redox potential interval $(410-470 \mathrm{mV})$ is associated with ferrous ion concentration between 0.125-0.215 mol $\mathrm{L}^{-1}$. The presence of bacteria generates an oxidizing atmosphere, which has an unfavorable effect in copper dissolution due to the high redox potential in these conditions and the high ferric ions concentration in solution.

\section{Conclusions}

The dissolution of chalcopyrite is favored by a simultaneous effect of ferrous ion concentration and redox potential interval: $0.125-0.215 \mathrm{~mol} \mathrm{~L}^{-1} \mathrm{Fe}^{2+}$ and 410-470 $\mathrm{mV}$. Iron precipitates and elemental sulfur did not affect copper dissolution in any abiotic conditions studied.

Presence of ferrous ions in abiotic systems enhanced significantly chalcopyrite dissolution recovering over $99 \%$ of copper. High dissolution rates in chalcopyrite leaching are related to the maintenance of low redox potential as well as the presence of ferrous ions in solution and both effects must be considered together.

\section{Acknowledgments}

The authors gratefully acknowledge financial support and scholarships from the Brazilian funding agencies: CNPq (ALAS for master fellowship), Additional support for this study was received from CAPES (ALA) and FAPESP (FAA proc. no 2010/13089-1 and DB, 19868-5/2011).

\section{References}

[1] Pradhan, N., Nathsarma, K.C., Srinivasa, R.K., Sukla, L.B., Mishra, B.K., Heap bioleaching of chalcopyrite: A review, Miner. Eng. 21 (2008) 355365. https://doi.org/10.1016/j.mineng.2007.10.018 
[2] Watling, H.R., The bioleaching of sulphide minerals with emphasis on copper sulphides - A review, Hydrometallurgy 84 (2006) 81-108. https://doi.org/10.1016/j.hydromet.2006.05.001

[3] Córdoba, E.M., Muñoz, J.A., Blázquez, M.L., González, F., Ballester A., Leaching of chalcopyrite with ferric ion. Part II: Effect of redox potential, $\begin{array}{llll}\text { Hydrometallurgy } & 93 & \text { (2008) 88-96. }\end{array}$ https://doi.org/10.1016/j.hydromet.2008.04.016

[4] Hackl, R.P., Dreisinger, D.B., Peters, E., King, J.A., Passivation of chalcopyrite during oxidative leaching in sulfate media, Hydrometallurgy 39 (1995) 25-48. https://doi.org/10.1016/0304-386X(95)00023-A

[5] Klauber, C., A critical review of the surface chemistry of acidic ferric sulphate dissolution of chalcopyrite with regards to hindered dissolution, Int. $\begin{array}{lllll}\text { J. } & \text { Miner. } & \text { Process. } & 86 & \text { (2008) }\end{array}$ https://doi.org/10.1016/j.minpro.2007.09.003

[6] Pinches, A., Myburgh, P.J., Merwe, C., Process for the rapid leaching of chalcopyrite in the absence of catalysis, Patent No: US 6, 277, 341 B1, 2001.

[7] Córdoba, E.M., Munoz, J.A., Blázquez, M.L., González, F., Ballester, A., Leaching of chalcopyrite with ferric ion. Part IV: the role of redox potential in the presence of mesophilic and thermophilic bacteria, Hydrometallurgy $93 \quad$ (2008) 106-115. https://doi.org/10.1016/j.hydromet.2007.11.005

[8] Shiers, D.W., Ralph, D.E., Watling, H.R., The effects of nitrate on substrate utilisation by some iron(II)- and sulfur-oxidising Bacteria and Archaea,

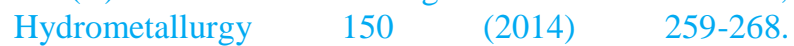
https://doi.org/10.1016/j.hydromet.2014.07.009

[9] Hiroyoshi, N., Kitagawa, H., Tsunekawa, M., Effect of solution composition on the optimum redox potential for chalcopyrite leaching in sulfuric acid solutions, Hydrometallurgy. 91 (2008) 144-149. https://doi.org/10.1016/j.hydromet.2007.12.005

[10] Hiroyoshi, N., Tsunekawa, M., Okamoto, H., Nakayama, R., Kuroiwa, S., Improved chalcopyrite leaching through optimization of redox potential, Can. $\begin{array}{lllll}\text { Metall. } & \text { Q. } & 47 & \text { (2008) } & \text { 253-258. }\end{array}$ https://doi.org/10.1179/cmq.2008.47.3.253

[11] Guohua, G., Hu, K., Zhang, X., Xiong, X., Yang, H., The stepwise dissolution of chalcopyrite bioleached by Leptospirillum ferriphilum, Electrochim. Acta 103 (2013) $50-57$. https://doi.org/10.1016/j.electacta.2013.04.051
[12] Garcia Júnior, O., Isolation and purification of Thiobacillus ferrooxidans and Thiobacillus thiooxidans from some coal and uranium mines of Brazil, Rev. Microbiol. 22 (1991) 1-6.

[13] Tuovinen, O.H., Kelly, D.P., Studies on the growth of Thiobacillus ferrooxidans. I. Use of membrane filters and ferrous iron agar to determine viable number and comparison with carbon-14 dioxidefixation and iron oxidation as measures of growth, Archiv fur Mikrobiol. 88 (1973) 285-298. PMID:4684598

[14] Vogel, A.I., Colorimetria e Espectrofotometria. In Análise inorgânica quantitativa, 4th ed. Rio de Janeiro: Guanabara, Brasil, 1981; pp. 552-553.

[15] Bevilaqua, D., Leite, A.L.L.C., Garcia Júnior, O., Tuovinen, O.H., Oxidation of chalcopyrite with Acidithiobacillus ferrooxidans and Acidithiobacillus thiooxidans in shake flasks, Process Biochem. 78 (2002) 587-592. https://doi.org/10.1016/S00329592(02)00169-3

[16] Bevilaqua, D., Lahti-Tommila, H., Garcia Junior, O., Puhakka, J.A., Tuovinen, O., Bacterial and chemical leaching of chalcopyrite concentrates as affected by the redox potential and ferric/ferrous iron ratio at $22{ }^{\circ} \mathrm{C}$, Int. J. Miner. Process. 132 (2014) 1-7. https://doi.org/10.1016/j.minpro.2014.08.008

[17] Bevilaqua, D., Diéz-Perez, I., Fugivara, C. S., Sanz, F., Benedetti, A. V., Garcia Jr., O. Oxidative dissolution of chalcopyrite $\left(\mathrm{CuFeS}_{2}\right)$ by Acidithiobacillus ferrooxidans analyzed by electrochemical impedance spectroscopy and atomic force microscopy, Bioelectrochemistry 64 (2004) 7984. https://doi.org/10.1016/j.bioelechem.2004.01.006

[18] Arena, F.A., Suegama, P.H., Bevilaqua, D., Santos, A.L., Fugivara, C.S., Benedetti, A.V., Simulating the main stages of chalcopyrite leaching and bioleaching in ferrous ions solution: An electrochemical impedance study with a modified carbon paste electrode, Miner. Eng. 92 (2016) 229-241. https://doi.org/10.1016/j.mineng.2016.03.025

[19] Gómez, E., Blázquez, M.L., Ballester, A., González, F., Study by SEM and EDS of chalcopyrite bioleaching using a new thermophilic bacteria, Miner. Eng. 9 (1996) 985-999. https://doi.org/10.1016/08926875(96)00089-1

[20] Li, Y., Kawashima, N., Li, J., Chandra, A.P., Gerson, A.R., A review of the structure, and fundamental mechanisms and kinetics of the leaching of chalcopyrite, Adv. Colloid Interfac. 197-198 (2013) 1-32. https://doi.org/10.1016/j.cis.2013.03.004 
[21] Third, K.A., Cord-Ruwisch, R., Watling, H.R., The role of iron-oxidizing bacteria in stimulation or inhibition of chalcopyrite bioleaching, Hydrometallurgy $\quad 57 \quad$ (2000) 225-233. https://doi.org/10.1016/S0304-386X(00)00115-8

[22] Córdoba, E.M., Muñoz, J.A., Blázquez, M.L., González, F., Ballester, A., Passivation of chalcopyrite during its chemical leaching with ferric ion at $68^{\circ} \mathrm{C}$, Miner. Eng. $22 \quad$ (2009) 229-235. https://doi.org/10.1016/j.mineng.2008.07.004

[23] He, H., Xia, J.-L., Hing, F.-F., Tao, X.-X., Leng, Y.-W., Zhao, Y.-D., Analysis of sulfur speciation on chalcopyrite surface bioleached with Acidithiobacillus ferrooxidans, Miner. Eng. 27-28 (2012) 60-64. https://doi.org/10.1016/j.mineng.2011.12.012
[24] Hiroyoshi, N., Miki, H., Hirajima, T., Tsunekawa, M., Enhancement of chalcopyrite leaching by ferrous ions in acidic ferric sulfate solution, Hydrometallurgy 60 (2001) 185-197. https://doi.org/10.1016/S0304$386 \times(00) 00155-9$

[25] Gericke, M., Govender, Y., Pinches, A., Tank bioleaching of low-grade chalcopyrite concentrates using redox control, Hydrometallurgy 104 (2010) 414419. https://doi.org/10.1016/j.hydromet.2010.02.024

[26] Third, K.A., Cord-Ruwisch, R., Watling, H.R., Control of the redox potential by oxygen limitation improves bacterial leaching of chalcopyrite, Biotechnol. Bioeng. 78 (2002) 433-441. 